\title{
Role of Packaging in Society and the Environment ${ }^{1}$
}

Kenneth Berger ${ }^{2}$

\section{Impacts of Packaging}

According to a 1990 report from the U.S. Environmental Protection Agency, the largest segment of municipal solid waste is the Containers/Packaging component. Whether by weight (32 percent) or by volume (30 percent), containers and packaging products are the dominant materials in the waste stream.

Packaging is so abundant in the solid waste system because it impacts so many aspects of life, commercially as well as privately. In fact, modern society could not exist without a mature and advanced packaging system, and packaging coincides with society's wants and needs. We choose what packaging is used by what we purchase.

Three-quarters of all finished goods require a package and ninety percent of that packaging market is within the food and drink industry. Additional areas requiring packaging are auto/hardware, housewares, and tobacco products.

The cost of the packaging as a percentage of total selling price varies greatly. Although this cost ranges from 1.4 percent to 40 percent, the average cost of packaging is $\$ 1$ for every $\$ 11$ spent. Nine percent of the amount you spend on any product is probably the cost of its packaging.

The package designs are planned to reflect the many changing social and economic trends in the world. Several of those trends and resulting examples include:

- health consciousness (nutrient and additive contents)

- family size/singles (different portions)

- economy (various sizes, quality levels)

- mobility (convenience items)

- novelty (over 150 new food and drug items are introduced every month in the U.S.)

- labeling requirements (contents and directions)

- available equipment (products for the freezer or microwave)

- time and convenience to purchase and use (various available sizes, complete meals in a package)

1. This document is ABE336, one of a series of the Agricultural and Biological Engineering Department, Florida Cooperative Extension Service, Institute of Food and Agricultural Sciences, University of Florida. First published Dec 2002. Minor revision: Dec 2003. Please visit the EDIS Web site at http://edis.ifas.ufl.edu.

2. Kenneth Berger, assistant professor, Agricultural and Biological Engineering Department, Institute of Food and Agricultural Sciences, University of Florida, Gainesville.

The Institute of Food and Agricultural Sciences is an equal opportunity/affirmative action employer authorized to provide research, educational information and other services only to individuals and institutions that function without regard to race, color, sex, age, handicap, or national origin. For information on obtaining other extension publications, contact your county Cooperative Extension Service office. Florida Cooperative Extension Service/Institute of Food and Agricultural Sciences/University of Florida/Christine Taylor Waddill, Dean. 
- consumerism (consumer complaints have the highest influence on pharmaceutical and health-related products)

- customs and social habits (beverage packaging)

- environmental concerns (reduced, reusable, recyclable packaging and recovery as energy)

Although packaging seems to be so prevalent, most packages serve at least one purpose and can be categorized as to type.

\section{Three Types of Packaging}

There are three types of packaging, depending on use. The container that directly holds the product is the primary package. That may be a can, bottle, jar, tube, carton, drum, etc.

Any outer wrappings that help to store, transport, inform, display and protect the product are secondary packaging. The decorated carton or gift box are common examples.

Lastly, tertiary packaging is used to group products for storage and transportation. The corrugated, brown carton is the most familiar. Large pallets of shrink-wrapped boxes are a common warehouse sight reflecting tertiary packaging.

For any product, from one to all three types of packaging may be necessary depending on the intended purpose.

\section{Five Purposes of Packaging}

Each package for any product basically serves up to five of the following purposes:

CONTAIN -- To hold the product directly; this is PRIMARY packaging. Examples include the tube or pump for toothpaste, the can or jar for a food item, the bottle for a beverage, and the drum for a cleaning product.

INFORM -- To identify the brand and any related companies, to explain how it should be used, to warn about the hazards for misuse, and to reveal product contents. Much of this information is required according to various laws and agencies.
PROTECT -- To prevent spoilage, leakage, breakage, moisture changes, theft and tampering. These packages: seal out contaminants in the environment (germs, dirt, dust, moisture, etc.); protect against tampering, theft, breakage, and spoilage.

TRANSPORT -- To easily and safely move the product from the manufacturer, perhaps to a warehouse, then to the retailer and finally, to the consumer. Instead of all communities manufacturing all goods for their residents, costs are reduced when production centers can specialize in the development of a particular item. Parts and/or products can then be transported to communities when completed and/or needed. And storage space at these various locations can be used much more efficiently when cartons are stacked.

DISPLAY -- To attractively display, to sell (a marketing tool). Size, cost, colors, brands, illustrations and shape are all considered for display. As this country changed from the sales person mode to self-service, the package was needed to inform and sell the product. With 10,000 products available in today's typical supermarket, a virtual "jungle" exists. So companies find that investments in packaging bring higher returns than traditional advertising.

Once an afterthought, the package design of today is an integral part of most products you buy.

As an example, give yourself a quiz the next time you are shopping. With one or two products, try to identify which type (PRIMARY, SECONDARY, TERTIARY) of packaging is involved and what purpose(s) it serves (CONTAINS, INFORMS, PROTECTS, TRANSPORTS, DISPLAYS).

\section{Resources}

Ohio State University Extension Fact Sheet, Community Development, 700 Ackerman Road, Suite 235, Columbus, OH 43202-1578, Purposes of Packaging, CDFS 134, Paula Hook and Joe E. Heimlich.

Fundamentals of Packaging Technology, Walter Soroka, 2000, published by Institute of Packaging Professionals. 